\title{
1 Extensive marine anoxia associated with the Late Devonian Hangenberg Crisis
}

3 Feifei Zhang ${ }^{1,2,3^{*}}$, Tais W. Dahl' ${ }^{2}$, Timothy M. Lenton ${ }^{4}$, Genming Luo ${ }^{5}$, Shu-zhong Shen ${ }^{1}$,

4 Thomas J. Algeo ${ }^{5,6,7}$, Noah Planavsky ${ }^{3}$, Jiangsi Liu ${ }^{5}$, Ying Cui ${ }^{8}$, Wenkun Qie ${ }^{9}$, Stephen J.

5 Romaniello ${ }^{10}$, Ariel D. Anbar ${ }^{10,11}$

6

$7{ }^{1}$ School of Earth Sciences and Engineering, Nanjing University, 163 Xianlin Avenue, $8 \quad$ Nanjing 210023, China

$9 \quad{ }^{2}$ Globe Institute, University of Copenhagen, København K, Denmark

$10{ }^{3}$ Department of Geology and Geophysics, Yale University, New Haven, CT 06511, U.S.A.

$11{ }^{4}$ Global Systems Institute, University of Exeter, Exeter EX4 4QE, UK

$12{ }^{5}$ State Key Laboratory of Biogeology and Environmental Geology, China University of 13 Geosciences, Wuhan, Hubei 430074, China

$14{ }^{6}$ State Key Laboratory of Geological Processes and Mineral Resources, China University 15 of Geosciences, Wuhan, Hubei 430074, China

$16{ }^{7}$ Department of Geology, University of Cincinnati, Cincinnati, OH 45221-0013, U.S.A.

$17{ }^{8}$ Department of Earth and Environmental Studies, Montclair State University, Montclair, $18 \quad$ New Jersey 07043, USA

$19{ }^{9}$ Nanjing Institute of Geology and Palaeontology, Chinese Academy of Sciences, Nanjing 20 210008, China

$21{ }^{10}$ School of Earth and Space Exploration, Arizona State University, Tempe, AZ 85287, $22 \quad$ U.S.A.

$23{ }^{11}$ School of Molecular Sciences, Arizona State University, Tempe, AZ, 85287, U.S.A. 
$24{ }^{*}$ Corresponding author: Feifei Zhang

25 School of Earth Sciences and Engineering,

26 Nanjing University

27163 Xianlin Avenue

28 Nanjing 210023, China

29 Tel: +8617771789784

30 Email: zhangfeifei414@gmail.com.

32 Abstract

33 The global Hangenberg Crisis near the Devonian-Carboniferous boundary (DCB)

34 represents one of the major Phanerozoic mass extinction events, which shaped the roots of

35 modern vertebrate biodiversity. Marine anoxia has been cited as the proximate kill

36 mechanism for this event. However, the detailed timing, duration, and extent of global

37 marine redox chemistry changes across this critical interval remain controversial because

38 most of the studies to date only constrain changes in local or regional redox chemistry.

39 Thus, opinions on the significance of anoxia as a kill mechanism are variable - from anoxia

40 being a primary driver to being relatively unimportant. In this study, we explore the

41 evolution of global marine redox chemistry using $U$ isotopes of marine limestones. The

$42 \delta^{238} \mathrm{U}$ trends at Long'an section in South China document systematic oscillations with three

43 negative shifts punctuated by two positive events in between. The magnitude of the $\delta^{238} \mathrm{U}$

44 oscillations implies that the sediments do not record contemporaneous seawater with a

45 constant offset at all times. The lack of covariation between $\delta^{238} \mathrm{U}$ data and diagenetic

46 indicators (e.g., $\mathrm{Mn}$ and $\mathrm{Sr}$ contents, $\mathrm{Mn} / \mathrm{Sr}$ ratio, $\delta^{18} \mathrm{O}$ ) suggests that the $\delta^{238} \mathrm{U}$ trends are 
47 not produced by the same post-depositional diagenetic processes. Instead, trace-metal

48 enrichments suggest that more reducing conditions prevailed during the deposition of the

49 two positive events. We present plausible model scenarios that fit the observed $\delta 238 \mathrm{U}$

50 trends in the context of redox-sensitive trace metal data suggesting marine anoxia expanded

51 in the latest Devonian oceans to cover $>5 \%$ of the continental shelf seafloor area. The rapid

52 expansion of marine anoxia coincident with the onset of the Hangenberg Crisis supports

53 marine anoxia as an important kill mechanism. Biogeochemical modeling of the coupled

54 C-P-U cycles suggests that intensified continental weathering, for example, assisted by the

55 spread of seed plants with deeper root systems at this time, could have triggered expansion

56 of marine anoxia and other global changes (e.g., positive excursion in $\delta^{13} \mathrm{C}_{\text {carb }}$ and decrease

57 in sea surface temperature) in the latest Devonian. The anoxic event is inferred to have

58 been transient as climatic cooling would have reduced weathering fluxes.

60 Keywords: Devonian-Carboniferous; mass extinction; Hangenberg Crisis; marine anoxia;

61 uranium isotopes; biogeochemical model

62

\section{1. Introduction}

64 The Late Devonian mass extinction, which occurred in two main phases between 65375 and $359 \mathrm{Ma}$, is one of the "Big Five" mass extinctions in Earth history, marked by a $6670-82 \%$ extinction rate among marine invertebrate species (Sallan and Coates, 2010). The 67 Late Devonian mass extinction comprised a series of extinction pulses. The main crises 68 occurred at the Frasnian-Famennian stage boundary ( $\sim 374 \mathrm{Ma})$ and during the Hangenberg 69 Event close to the Devonian-Carboniferous transition ( 359 Ma) (Sallan and Coates, 2010; 
70 Becker et al., 2012; Kaiser et al., 2016). Various causes for these extinctions have been

71 proposed, including volcanism, climate change, sea-level changes, global cooling,

72 submarine hydrothermal activity, and/or expansion of marine anoxia/euxinia (e.g.,

73 Joachimski and Buggisch, 2002; Tribovillard et al., 2004; Joachimski et al., 2009; White

74 et al., 2018).

75 Recent work has provided new insights into environmental changes associated with

76 the latest Devonian Hangenberg extinction. Widespread marine anoxia at that time is

77 recorded by globally extensive black, organic-rich mudrock deposition (Algeo et al., 1995;

78 Caplan and Bustin, 1999; Marynowski and Filipiak, 2007; Marynowski et al., 2012; Becker

79 et al., 2016; Kaiser et al., 2016). High-resolution chemostratigraphic studies have provided

80 detailed records of environmental changes in specific regions. In deep-water black shales

81 of central Poland, there is evidence for the development of photic-zone euxinia from green-

82 sulfur bacterial biomarkers (Marynowski and Filipiak, 2007) as well as pyrite framboid

83 size distributions and significant trace metal evidence (Marynowski et al., 2012). In

84 shallow-marine carbonate sections in South China, bulk nitrogen isotope variations suggest

85 locally enhanced nitrogen fixation, possibly as a consequence of increased denitrification

86 in response to expanded marine anoxia (Liu et al., 2016), and I/Ca ratios suggest expansion

87 of the oxygen minimum zone into the ocean-surface layer (Liu et al., in press). There is

88 abundant evidence for redox shifts during the latest Devonian, but all previous studies

89 focused on local or regional redox chemistry changes - in many cases from semi-isolated

90 settings. Therefore, the secular evolution of global marine redox conditions during the

91 latest Devonian remains poorly constrained, despite its importance for understanding

92 global cause-and-effect relationships during the Hangenberg extinction event. 
To fill this gap, we investigated the uranium isotope composition of marine

94 limestones (denoted as $\delta^{238} \mathrm{U}$ ), a proxy that can be used to place quantitative constraints on

95 global marine redox chemistry changes (e.g., Dahl et al., 2014; Lau et al., 2016, 2017;

96 Clarkson et al., 2018; Zhang et al., 2018a, b, c; White et al., 2018; Zhang et al., 2019a, b),

97 in the Long'an section, South China, which captured the Hangenberg extinction event. We

98 then used a global uranium cycle model to explore the timing, duration, and extent of global

99 marine redox changes during the Hangenberg extinction event. Finally, we used a global

100 model of C-P-U cycling to test the hypothesis that the spread of seed plants and an

101 associated increased P release could have triggered this event.

\section{2. Geological background}

104 The Long'an section is located on the South China Craton, which was situated in 105 the eastern Tethys Ocean close to the equator during the Devonian-Carboniferous transition 106 (Fig. 1). At that time, the southern (paleo-eastern) margin of the South China Craton 107 consisted of a large marine embayment, comprising many shallow carbonate platforms (the 108 Xianggui-Qiangui platform complex) and deep-water troughs of which the Youjiang Basin

109 was the largest. The proximal platforms were attached to the southern margin of the South

110 China Craton, whereas the distal platforms were isolated from land areas by intervening 111 troughs.

112 The Long'an section is located in Dujie Village of Long'an County in Guangxi 113 Zhuang Autonomous Region $\left(23^{\circ} 10^{\prime} 34.8^{\prime \prime} \mathrm{N} ; 1^{\prime} 107^{\circ} 27^{\prime} 48.0^{\prime \prime}\right.$ E). The litho- and 114 biostratigraphy of the study section were described in detail by Qie et al. (2015) and Liu et 115 al. (2016). Briefly, the 38-m-thick Long'an section is divided into the Yonghsien and 
116 Long'an formations (Fig. 2). The Yonghsien Formation ( -30 to $0 \mathrm{~m}$ ) consists mainly of

117 massive bioclastic wackestone, packstone, and grainstone, whereas the Long'an Formation

118 (0 to $8 \mathrm{~m}$ ) is dominated by thin-bedded calcisphere wackestone and packstone. The $\mathrm{D}-\mathrm{C}$

119 boundary, which is defined by the first appearance of the conodont Siphonodella sulcata

120 (a linear descendant of S. praesulcata) is located at $\sim 6 \mathrm{~m}$ above the base of the Long'an

121 Formation, and the base of the Upper praesulcata and Middle praesulcata zones are

122 located at $\sim 2 \mathrm{~m}$ and $\sim 3.3 \mathrm{~m}$ below the base of the Long'an Formation, respectively (Qie et

123 al., 2015; Liu et al., 2016). Sedimentological evidence (i.e., presence of bioturbation)

124 indicates that the entire study interval was deposited in an oxic shallow-marine setting (Qie

125 et al., 2015), consistent with the study units being passive recorders of seawater $U$ isotope

126 composition with an offset similar to that in modern Bahamian carbonate sediments

127 (Romaniello et al., 2013; Chen et al., 2018).

128 In this study, 55 nearly pure limestone samples $\left(\mathrm{CaCO}_{3}\right.$ content from $92.7 \%$ to $99.9 \%$

129 with a mean of $98.5 \%$; see Liu et al., 2016) were analyzed for $\delta^{238} \mathrm{U}$ and major and trace

130 elements. $\delta^{13} \mathrm{C}_{\text {carb }}, \delta^{15} \mathrm{~N}_{\text {bulk }}$, and I/Ca ratio data from the same suite of samples have been

131 previously reported by Qie et al. (2015), Liu et al. (2016), and Liu et al. (in review).

\section{3. Analytical methods}

134 Three to five grams of carbonate powder were dissolved in $1 \mathrm{M}$ hydrochloric acid

$135(\mathrm{HCl})$ for $24 \mathrm{~h}$ at room temperature. Digests were centrifuged and the supernatant was

136 separated. A split of each supernatant was diluted to $200 \mathrm{ppm}$ calcium $(\mathrm{Ca})$ with $2 \%$

$137 \mathrm{HNO}_{3}$ and analyzed for a full suite of major and trace element concentrations on a Thermo

138 iCAP quadrupole inductively coupled plasma mass spectrometer (Q-ICP-MS) at the W. M. 
139 Keck Laboratory for Environmental Biogeochemistry at Arizona State University (ASU).

140 Typical precision was better than $3 \%$ and $5 \%$ for major and trace elements, respectively,

141 based on repeated analysis of in-run standards.

142 Prior to U purification by ion exchange chromatography, appropriate amounts of $143{ }^{236} \mathrm{U}:{ }^{233} \mathrm{U}$ double spike (e.g., Romaniello et al., 2013; Zhang et al., 2018a, b, c; Chen et al., 144 2018; Zhang et al., 2019a,b) were added to each sample to correct for instrumental and 145 procedural mass-dependent fractionation of the measured ${ }^{238} \mathrm{U} /{ }^{235} \mathrm{U}$ ratio. The spike146 sample mixtures were evaporated to dryness and taken up in $3 \mathrm{~N} \mathrm{HNO}_{3}$. Uranium was 147 purified using the UTEVA method (e.g., Romaniello et al., 2013; Chen et al., 2018; Zhang 148 et al., 2018a, b, c; White et al., 2018 for details) before isotopic analysis. All samples were 149 put through UTEVA resin twice in order to completely remove matrix ions. The final 150 purified $\mathrm{U}$ was dissolved in $0.32 \mathrm{M} \mathrm{HNO}_{3}$ and diluted to a $\mathrm{U}$ concentration of $50 \mathrm{ppb}$.

151 Uranium isotopes were measured at ASU on a Thermo-Finnigan Neptune multi-collector 152 ICP-MS at low mass resolution. The standard solution CRM145 (50 ppb U) was analyzed 153 every two samples. Two secondary standards CRM129a and Ricca ICP solution were 154 measured after every fifteen measurements. Sample $\delta^{238} U$ values were normalized by the 155 average of the bracketing standards. The $\delta^{238} \mathrm{U}$ results are summarized in Figure 2 in the 156 main text and in the Supplementary Data file.

158 4. Results

$159 \delta^{238} \mathrm{U}$ values at the Long'an section range from $-0.82 \%$ to $+0.32 \%$ (see Fig. 2 and 160 Supplementary Data file). The $\delta^{238} \mathrm{U}$ data display a coherent curve with three negative 161 excursions (N1 to N3) separated by two positive excursions (P1 and P2; Fig. 2). The N1 
162 event (a $\sim 0.6 \%$ negative shift) began in the uppermost Lower Siphonodella praesulcata

163 Zone and ended in the lower Middle S. praesulcata Zone. The N2 event (a 1.0\%o negative

164 shift) began in the lower Upper S. praesulcata Zone and ended in the upper Upper $S$.

165 praesulcata Zone. The N3 event (a $\sim 0.8 \%$ negative shift) began in the uppermost Upper $S$.

166 praesulcata Zone and ended in the lower $S$. sulcata-S. duplicata zones. Using the measured

167 thicknesses of conodont biozones at Long'an (Qie et al., 2015; Liu et al., 2016, 2018) and

168 the radiometric Devonian time scale of Becker et al. (2012), in which the duration of each

169 conodont zone was calibrated, we calculated an average sedimentation rate of $\sim 37 \mathrm{~m} / \mathrm{Myr}$

170 and a total duration of $\sim 1$ Myr for the study interval. We are not implying perfectly linear

171 sedimentation, but a total duration of $\sim 1 \mathrm{Myr}$ is supported by a robust biostratigraphic

172 framework.

173

174 5. Discussion

1755.1 Evaluation of post-depositional alteration of $\delta^{238} U$ signals in the Long'an section

176 The carbonate $U$ isotope redox proxy is a relatively new proxy compared to

177 traditional carbonate $\mathrm{C}, \mathrm{O}$, and $\mathrm{Sr}$ isotope systematics. Modern carbonate samples from the

178 Bahamas yield ${ }^{238} \mathrm{U}$ values with an offset range from 0 to $0.5 \%$ with an average of

$1790.27 \pm 0.14 \%$ (1 SD) relative to the overlying seawater (Romaniello et al., 2013; Chen et

180 al., 2018). This offset is generated syndepositionally close to the sediment-water interface

181 (Romaniello et al., 2013). This is a common feature in carbonate sediments, although the

182 redox states of the sediment porewater played an important role (Romaniello et al., 2013),

183 there is still some uncertainty about the processes governing the magnitude of this offset.

184 Samples with evidence for more open-system diagenetic exchange (low $\mathrm{Sr} / \mathrm{Ca}$, high $\mathrm{Mn} / \mathrm{Sr}$ ) 
185 have been shown to yield slightly greater offsets (Dahl et al., in review). However, 186 diagenetic modeling suggests that preservation of carbonate $\delta^{238} \mathrm{U}$ signals should be 187 substantially more robust during fluid exchange than $\delta^{18} \mathrm{O}$ and ${ }^{87} \mathrm{Sr} /{ }^{86} \mathrm{Sr}$ (Lau et al., 2017; 188 Chen et al., 2018), and comparisons of deep drill core samples further confirm that $\delta^{238} U$ 189 is not affected to the same degree as $\delta^{13} \mathrm{C}$ and $\delta^{18} \mathrm{O}$ (Chen et al., 2018; Tissot et al., 2018). 190 In this study, we evaluated potential diagenetic alteration using conventional 191 geochemical criteria. Low Mn contents, high Sr contents, low Mn/Sr ratios, and relatively 192 high $\delta^{18} \mathrm{O}$ values are characteristic of carbonate sediments with minimal influence by 193 meteoric diagenesis (e.g., Banner and Hanson, 1990; Jacobsen and Kaufman, 1999; Lau et 194 al., 2016; White et al., 2018; Zhang et al., 2019a). In the Long'an section, Mn contents 195 vary from $11.5 \mathrm{ppm}$ to $90 \mathrm{ppm}$ with a mean of $35 \mathrm{ppm}, \mathrm{Sr}$ contents vary from $168 \mathrm{ppm}$ to $196557 \mathrm{ppm}$ with a mean of $310 \mathrm{ppm}$, and $\mathrm{Mn} / \mathrm{Sr}$ ratios vary from 0.03 to 0.33 with a mean of 197 0.12. These characteristics are consistent with well-preserved marine carbonates with 198 minimal chemical alteration during burial diagenesis (e.g., Banner and Hanson, 1990; 199 Jacobsen and Kaufman, 1999; Lau et al., 2016; White et al., 2018; Zhang et al., 2019a; Fig. $200 \mathrm{~S} 1$ in the supplementary material). This hypothesis is further supported by O isotope data $201\left(\delta^{18} \mathrm{O}\right.$ values $\left.>-6 \%\right)$, which are within the typical range of best preserved Phanerozoic 202 marine carbonate $\delta^{18} \mathrm{O}$ values (e.g., Veizer et al., 1999). Therefore, we infer that interaction 203 with meteoric or burial fluids is unlikely to have significantly altered the $\delta^{238} U$ record at 204 Long'an.

205 Changes in lithology—such as dolomitization — are not a concern in the study 206 section. The $\mathrm{Mg} / \mathrm{Ca}$ molar ratios in the samples are well below 0.01 , suggesting negligible 207 dolomitization. Other changes in mineralogy—such as the transformation of aragonite to 
208 calcite — can release U into pore fluids. This transformation, however, generally occurs at 209 greater burial depths at which insoluble U(IV) is stable and, thus, any U isotope 210 fractionation in the limestones will be muted or not expressed (Henderson et al., 1999; 211 Romaniello et al., 2013; Chen et al., 2016; Chen et al., 2018). Further, there is no 212 relationship to bulk carbonate $\mathrm{Sr} / \mathrm{Ca}$ ratios, which are sensitive to aragonite dissolution and

213 Sr capture in secondary calcite phases, which suggests a limited influence from aragonite214 to-calcite transition on observed $\delta^{238} \mathrm{U}$ trends.

215 Contamination from detrital materials is also not a concern for $\delta^{238} \mathrm{U}$ in the study 216 section. Dissolution of carbonate sediments using $1 \mathrm{M} \mathrm{HCl}$ has the potential to liberate $\mathrm{U}$ 217 from detrital materials. We evaluated this possibility based on $\mathrm{Al}$ concentrations and U/Al 218 ratios. Aluminium concentrations range from $8 \mathrm{ppm}$ to $133 \mathrm{ppm}$ with a mean of $39 \mathrm{ppm}$, 219 confirming that the study samples are relatively pure carbonates with low detrital content. 220 U/Al ratios, which range from 28 to $4114 \mathrm{ppm} / \mathrm{wt} . \%$, are significantly higher than the 221 average upper continental crustal value of $0.33 \mathrm{ppm} / \mathrm{wt} . \%$ (Rudnick and Gao, 2014) or the 222 topsoil mean value of $0.58 \pm 1.13 \mathrm{ppm} / \mathrm{wt} . \%$ (Cole et al., 2017), indicating that our sample 223 digestion protocol has effectively extracted carbonate-associated U. Even if some detrital $224 \mathrm{U}$ was extracted, it is quantitatively insignificant and does not affect the reported $\delta^{238} \mathrm{U}$ 225 values.

226 Although the analysis above indicates that Long'an carbonates were not strongly 227 altered by post-depositional diagenetic processes, the P1 interval is nonetheless enriched 228 in Fe, Zn, Mo, and U (Fig. 3), suggesting that it was influenced by sulfidic pore fluids in 229 the early diagenetic environment and/or by an input of dissolved metals to the global 230 oceans due to changes in terrestrial weathering. $\mathrm{Fe}, \mathrm{Zn}$, and Mo are redox-sensitive 
231 chalcophile metals that accumulate in sediments in which dissolved $\mathrm{H}_{2} \mathrm{~S}$ is present in pore

232 fluids (Tribovillard et al., 2006). During expansion of marine anoxia, rapid reduction of

233 seawater-soluble U(VI) can lead to massive accumulation of insoluble and isotopically

234 heavier U(IV) below the sediment-water interface. With dissolved $\mathrm{H}_{2} \mathrm{~S}$ present in sediment

235 pore fluids, isotopically heavy U(IV) can be incorporated into carbonate precipitates. This

236 process has been well documented on the modern Bahamian carbonate platform

237 (Romaniello et al., 2013). Although the overlying water column is well oxygenated,

238 Bahamian sediment pore-waters become sulfidic $\sim 5 \mathrm{~cm}$ below the sediment-water interface

239 as a result of abundant organic matter and high rates of respiration and sulfate reduction

240 (Romaniello et al., 2013). We acknowledge that $\mathrm{Fe}, \mathrm{Zn}$, and Mo concentrations in

241 carbonates can be biased by the incorporation of terrestrial Fe, Zn, and Mo contributions

242 (i.e., in association with an episode of enhanced terrestrial weathering input). This

243 possibility during the $\mathrm{P} 1$ event can, however, be ruled out by the Al normalized elemental

244 plots (Fe/Al, $\mathrm{Zn} / \mathrm{Al}$, and Mo/Al; Fig. 3) where stratigraphic spikes in $\mathrm{Fe}$, Mo, and $\mathrm{Zn}$ are

245 retained and, therefore, argue for authigenic Fe, Mo, and $\mathrm{Zn}$ enrichments during the P1

246 event. Building from these observations, we suggest that the pronounced U enrichments

247 and the high $\delta^{238} \mathrm{U}$ values of the P1 event were most likely a product of strongly reducing

248 pore-water conditions that induced significant authigenic U(IV) enrichments and thus a

249 larger-than-usual early diagenetic offset. This hypothesis has been further modeled in

250 section 5.3. Our study is limited to one section, and we encourage further studies of other

251 sections to assist in disentangling local from global $\mathrm{U}$ isotope signals.

252 In contrast to the P1 event, the P2 event exhibits only Fe and Zn enrichments but

253 no Mo enrichments, although $U$ concentrations are still enriched relative to adjacent 
254 sediments. The spikes in Fe and $\mathrm{Zn}$ during the P2 event, however, disappears when 255 normalized to $\mathrm{Al}$ concentrations (Fig. 3), suggesting that these spikes are mainly associated 256 with a terrestrial input of dissolved metals to the latest Devonian oceans and not driven by 257 local $\mathrm{Fe}$ and $\mathrm{Zn}$ sulfide precipitation in sulfidic porewaters. Given the fact that $\mathrm{Fe}, \mathrm{Zn}$, and

258 Mo sequestration in sediments is strongly enhanced by the presence of free $\mathrm{H}_{2} \mathrm{~S}$, reductive 259 immobilization of $\mathrm{U}$ is less sensitive to $\mathrm{H}_{2} \mathrm{~S}$ (Tribovillard et al., 2006), the lack of Fe/Al, $260 \mathrm{Zn} / \mathrm{Al}$, and $\mathrm{Mo} / \mathrm{Al}$ spikes within the P2 interval could indicate anoxic and non-sulfidic 261 pore-water conditions, which led only to small U enrichments (see section 5.3 for further 262 model interpretations). We, however, could not fully rule out the possibility that the P2 263 event represented a global ocean reoxygenation event; this possibility has been modeled in 264 section 5.4 using a C-P-U model, and distinguish between models in section 5.3 and 5.4 265 requires $\delta^{238} \mathrm{U}$ measurements from another section.

266 In the modern Bahamas, both bank-top and deep-slope carbonates have $\delta^{238} \mathrm{U}$ 267 compositions that are heavier than that of contemporaneous seawater by $0-0.5 \%$ (average 268 of $0.27 \pm 0.14 \%$ o, $1 \mathrm{SD})$. This offset is not constant and has been attributed to incorporation 269 of ${ }^{238} \mathrm{U}$-enriched U(IV) from anoxic pore waters during early diagenesis (Romaniello et al., 2702013 ) or variations in pore-water U-speciation during carbonate recrystallization (Chen et 271 al., 2018). The influence of syndepositional processes on carbonate $U$ are possible because 272 shallow, relatively permeable carbonates can sequester dissolved U(VI) from the overlying 273 oxic water column via advective and diffusive transport. This semi-open system behavior 274 allows an exchange of $U$ isotopes that can induce a net ${ }^{238} U$ offset in bulk carbonate 275 sediments relative to primary carbonate phases. As stated above, this process is not 276 significant at greater burial depths because the mobility of $U$ is severely restricted in anoxic 
277 pore fluids, as shown by nearly identical $\delta^{238} U$ offsets in Bahamian carbonates regardless

278 of mineralogy (e.g., aragonite, low-Mg calcite, or dolomite), water depth, and depth below

279 the sediment-water interface (Chen et al., 2018; Tissot et al., 2018). On this basis, we have

280 applied a diagenetic correction factor to measured $\delta^{238} U$ values prior to the $U$ isotope mass

281 balance calculations presented below.

\subsection{Quantifying marine redox changes using a uranium isotope mass balance model}

In order to quantitatively estimate the duration and extent of marine redox

285 variations, we used the $\mathrm{U}$ isotope mass balance model of Zhang et al. (2019a) (see also Lau

286 et al., 2016) to calculate the proportion of total marine $U$ burial in anoxic sediments $\left(f_{\text {anoxic }}\right)$

287 and to estimate the areal extent of marine anoxia in latest Devonian oceans (Aanoxic).

The implied changes to the extent of marine anoxia can be described by differential

289 mass balance equations for the seawater U reservoir and its source and sink fluxes:

$$
\frac{d N_{s w}}{d t}=J_{\text {river }}-J_{\text {anoxic }}-J_{\text {other }}
$$

$$
\frac{d\left(N_{\text {sw }} \cdot \delta^{238} U_{\text {sw }}\right)}{d t}=J_{\text {river }} \cdot \delta^{238} U_{\text {river }}-J_{\text {anoxic }} \cdot \delta^{238} U_{\text {anoxic }}-J_{\text {other }} \cdot \delta^{238} U_{\text {other }}
$$

$$
\delta^{238} U_{\text {anoxic }}=\delta^{238} U_{s w}+\Delta_{\text {anoxic }}
$$

$$
\delta^{238} U_{\text {other }}=\delta^{238} U_{\text {sw }}+\Delta_{\text {other }}
$$

294 Eq. (2) can be rewritten as:

$$
\frac{d\left(N_{s w} \cdot \delta^{238} U_{s w}\right)}{d t}=J_{\text {river }} \cdot \delta^{238} U_{\text {river }}-J_{\text {anoxic }} \cdot\left(\delta^{238} U_{\text {sw }}+\Delta_{\text {anoxic }}\right)-J_{\text {other }} \cdot\left(\delta^{238} U_{s w}+\Delta_{\text {other }}\right)
$$

296 where $N_{s w}$ is the oceanic uranium inventory in moles, $\delta^{238} \mathrm{U}_{\text {sw }}, \delta^{238} \mathrm{U}_{\text {river, }}, \delta^{238} \mathrm{U}_{\text {anoxic, }}$ and $\delta^{238} \mathrm{U}_{\text {other }}$ are the $\mathrm{U}$ isotope compositions of seawater, riverine sources, anoxic sedimentary 
sinks, and the average of the remaining other sinks, respectively. $J_{\text {river }}$ is the riverine $U$ flux in $\mathrm{mol} / \mathrm{yr}$. A $\Delta_{\text {anoxic }}=+0.6 \%$ is the average isotopic difference between anoxic/euxinic

300 sediments and contemporaneous seawater (e.g, Andersen et al., 2014), and $\Delta_{\text {other }}$ is the 301 average isotopic difference between contemporaneous seawater and the remaining other 302 sinks ( $+0.05 \%$, calculated to maintain an isotopic steady state in the modern ocean). Following prior studies (e.g., Dahl et al. 2014; Lau et al., 2016, 2017; Zhang et al., 304 2018b; Zhang et al., 2019a), we define $J_{\text {anoxic as: }}$

$$
J_{\text {anoxic }}=A_{\text {anoxic }} \cdot k_{\text {anoxic }} \cdot N_{s w}
$$

306 where Aanoxic is the total seafloor area overlain by anoxic waters and $k$ anoxic is the rate 307 constant associated with anoxic sediment deposition. Solving equations (1) and (2) at a 308 steady state, we have:

$$
f_{\text {anoxic }}=\frac{\delta^{238} U_{\text {river }}-\delta^{238} U_{\text {sw }}-\Delta_{\text {other }}}{\Delta_{\text {anoxic }}-\Delta_{\text {other }}}
$$

310 where $f_{\text {anoxic }}=J_{\text {anoxic }} / J_{\text {river, }}$ and the $\delta^{238}$ Usw of the latest Devonian oceans can be estimated 311 using observed $\delta^{238} \mathrm{U}$ data for Long' an minus the early diagenetic offset $\left(\Delta_{\text {offset, }}\right.$, the $\delta^{238} \mathrm{U}$ 312 difference between carbonate sediments and overlying seawater):

$$
\delta^{238} U_{s w}=\delta^{238} U_{c a r b}-\Delta_{\text {offset }}
$$

314 Measured carbonate $\delta^{238} \mathrm{U}$ for Long'an spans a wide range of values up to $+0.2 \%$.

315 These high values are beyond what can be achieved in open-ocean seawater (where $\delta^{238} U_{\text {sw }}$ $316<-0.28 \%=\delta^{238} U_{\text {river}}$; e.g., Andersen et al., 2017), and therefore these carbonates record 317 seawater with a substantial offset $\left(\delta^{238} U_{\text {carb }}-\delta^{238} U_{\text {sw }}=\Delta_{\text {offset }}\right)$. A positive $\Delta_{\text {offset }}$ is 318 consistent with that observed in drill cores from the modern Bahamian platform (i.e., $\Delta_{\text {offset }}$ 
319 ranges from 0 to $0.5 \%$ with an average of $+0.27 \pm 0.14 \%$, $1 \mathrm{SD}$; Chen et al., 2018; Tissot 320 et al., 2018). Larger $\Delta_{\text {offset }}$ up to $+0.6 \%$ are known to occur in reducing sediments with 321 substantial authigenic U(IV) enrichments (e.g., core 1 from the $T$. testudium flat in the 322 Bahamas; Romaniello et al. 2013). The relatively high $\delta^{238} \mathrm{U}$ values in the P1 and P2 323 intervals imply higher $\Delta_{\text {offset }}$ values at those times (i.e., due to anoxic/sulfidic porewater 324 conditions discussed in section 5.1), and these intervals are also characterized by greater $\mathrm{U}$ 325 enrichments than other intervals of the Long'an section.

326 To show that the ocean oxygenation state varied both at the global scale and in the 327 Long'an basin, we first calculated steady state $f_{\text {anoxic }}$ values from Eqs. (7) and (8) assuming 328 constant values for $\Delta_{\text {offset }}$ of $0 \%$, $+0.27 \%$, and $+0.6 \%$ (Fig. 4 ). The other model parameters 329 are given in Table 1. In order to avoid overinterpretation of noise in the $\delta^{238} U_{\text {carb }}$ dataset,

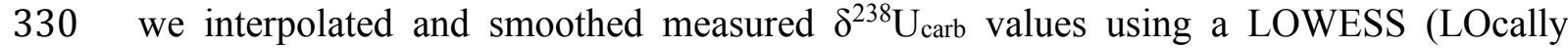
331 WEighted Scatterplot Smoothing) fit method with a span parameter equal to 0.4. The 332 isotope-driven calculation of $\mathrm{f}_{\text {anoxic }}$ values shows that the $\mathrm{U}$ burial flux into anoxic 333 sediments was significantly greater during the N1, N2, and N3 intervals than today.

$334 \quad$ All three curves (based on $\Delta_{\text {offset }}$ of $0 \%,+0.27 \%$, and $+0.6 \%$ ) show fanoxic values 335 that are not possible within global U mass balance constraints for some time intervals (i.e.,

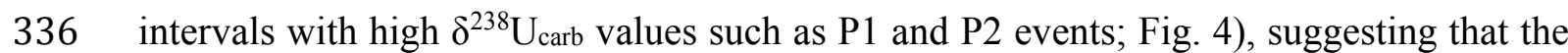
$337 \Delta_{\text {offset }}$ was not constant and must have varied temporally during accumulation of the 338 Long'an carbonates. We model this possibility by simultaneously changing $\mathrm{A}_{\text {anoxic }}$ and $339 \Delta_{\text {offset }}$ in Equations (5), (7) and (8) to generate the $\delta^{238} U_{\text {carb }}$ trend observed in the Long'an 340 section. Although this approach gives a range of fanoxic solutions for the Long'an dataset, 341 we can nonetheless draw certain conclusions about the solution space. We provided two 
342 distinct model scenarios to explain the observed $\delta^{238} \mathrm{U}_{\text {carb }}$ trend of the Long' an section (Fig.

343 5) that allow higher $\Delta_{\text {offset }}$ values at P1 and P2 where elevated Mo and/or U enrichments

344 indicate more reducing pore-water conditions in the early diagenetic environment (Figs. 3

345 and 5).

346 The first modeled scenario (Fig. 5, model scenario 1) started from an oxygenated 347 ocean similar to that of the modern, with the onset of anoxic expansion at the peak of P1

348 ( 359.1 Ma). The second scenario (Fig. 5, model scenario 2) started from the same baseline 349 as the first scenario but incorporated an earlier expansion of anoxia $(\sim 359.2 \mathrm{Ma})$ where the

$350 \mathrm{U}$ concentration begins to drop. The first modeled scenario fits the $\delta^{238} \mathrm{U}_{\text {carb }}$ trend of 351 Long'an better, and it also produces a distribution of $\Delta_{\text {offset }}$ similar to that observed in 352 modern Bahamian carbonates (Fig. 6), but it fails to mirror the observed U concentration 353 profile. In contrast, the second modeled scenario fits the observed U concentration trend 354 better, but it cannot fully fit the peak of the $\delta^{238} \mathrm{U}_{\text {carb }}$ trend at P1 because $\Delta_{\text {offset }}$ becomes 355 larger than for modern carbonates but is limited to $0.6 \%$ in our model (Fig. 6). $\delta^{238} \mathrm{U}$ offset 356 distribution test supports that our modelled seawater $\delta^{238} U$ curve is realistic, but it does not 357 rule out other plausible seawater $\delta^{238} U$ curves. This will not be resolved until new $\delta^{238} U_{\text {carb }}$ 358 curves are generated at other sections. Nevertheless, both model scenarios suggest that 359 global marine anoxia expanded significantly, covering $>5 \%$ of continental shelf areas in 360 the latest Devonian oceans. The maximal extent of marine anoxia is difficult to constrain 361 because modeled $\delta^{238} \mathrm{U}$ is insensitive to expanding anoxia once the anoxic $\mathrm{U}$ sink 362 dominates other U sink fluxes. However, a $>5 \%$ expansion of anoxic marine zones is large 363 enough to have extended over most continental shelf areas, which account for just $7.6 \%$ of 364 total seafloor area in the modern ocean. The expansion of marine anoxia was coincident 
with the onset of the Hangenberg Crisis at the base of the Middle Siphonodella praesulcata

366 Zone (Fig. 5). The modelled fanoxic curves in Fig. 5 are consistent with the observation that

367 U concentrations overall decrease across the anoxic event in tandem with the changes in

$368 \mathrm{I} / \mathrm{Ca}$ and nitrogen isotopes (Liu et al., 2016, in press). A full recovery to the pre-expansion

369 background state is, however, not recorded in the studied Long'an section.

370 Both model scenarios can explain the observed P1 and P2 events at the Long'an

371 section by invoking redox changes in the sediment pore-water environment. According to

372 the model, these positive events can be reasonably explained by intensified anoxic/sulfidic

373 conditions in the sediment pore fluids (or in theory the water column above the water-

374 sediment interface based on $\mathrm{I} / \mathrm{Ca}$ and $\delta^{15} \mathrm{~N}$ evidence from the Long'an section; Liu et al.,

375 2016, in press), which precipitated ${ }^{238}$ U-enriched U(IV) into the Long'an carbonates during

376 the P1 and P2 intervals. For example, our model shows that $\Delta_{\text {offset }}$ values must have

377 approached $+0.6 \%$ in the P1 interval and +0.4 to $+0.6 \%$ in the P2 interval (Fig. 5).

378 Our $\delta^{238} \mathrm{U}$ data, along with biomarker and other evidence for widespread oceanic 379 anoxia elsewhere globally (Algeo et al., 1995; Caplan and Bustin, 1999; Marynowski and

380 Filipiak, 2007; Marynowski et al., 2012; Liu et al., 2016; Liu et al., in press), confirm that 381 a large proportion of latest Devonian outer continental shelves and upper slopes were 382 covered by anoxic waters. The expansion of marine anoxia would have promoted extensive 383 black, organic-rich mudrock deposition (Algeo et al., 1995; Caplan and Bustin, 1999) and 384 allowed the buildup of $\mathrm{H}_{2} \mathrm{~S}$ in shallow-water environments (Marynowski and Filipiak, 385 2007; Marynowski et al., 2012). It also increased sediment burial of reduced carbon and 386 sulfur relative to oxidized forms, leading to large positive shifts in $\delta^{13} \mathrm{C}_{\text {carb }}$ and $\delta^{34} \mathrm{~S}_{\mathrm{CAS}}$ 387 globally (Brand et al., 2004; Kaiser et al., 2006, 2008; Qie et al., 2015; Liu et al., 2016). 
3895.3 Testing links of marine anoxia to the spread of land plants and enhanced chemical

390 weathering

391 The Late Devonian was a key interval in the evolutionary history of land plants, as

392 the appearance of the earliest seed plants allowed the spread of terrestrial vegetation into

393 upland areas for the first time (Algeo et al., 1995; Berner et al., 1997; Algeo and Scheckler,

394 1998). This event is thought to have resulted in a decrease of atmospheric $\mathrm{CO}_{2}$ levels and

395 a longer-term increase of atmospheric $\mathrm{O}_{2}$ levels as well as to have had a deep influence on

396 marine biogeochemical cycles (Algeo et al., 1995; Berner et al., 1997; Lenton et al., 2001).

397 The spread of vascular plants and an associated intensification of continental weathering

398 has been proposed to have increased marine phosphorus levels, thus generating higher

399 marine productivity and an expansion of marine anoxic seafloor areas in latest Devonian

400 oceans (Algeo et al., 1995; Algeo and Scheckler, 1998). Intensified continental weathering

401 is supported by an increase in ${ }^{87} \mathrm{Sr} /{ }^{86} \mathrm{Sr}$ from $\sim 0.70813$ to $\sim 0.70829$ during the Late

402 Devonian (Brand et al., 2004; McArthur et al., 2012). Conodont apatite oxygen-isotope

403 data imply a concurrent $\sim 3{ }^{\circ} \mathrm{C}$ decrease in tropical sea-surface temperatures during the

404 latest Devonian (Joachimski et al., 2009) consistent with more intensive weathering.

405 However, on a million-year time scale, the overall amount of silicate weathering is must

406 be close to be in balance with carbon dioxide outgassing rates, similar to what is observed

407 for the Cenozoic (e.g., Berner and Caldeira, 1997; Caves et al., 2016). In this light, the

408 effect of land plants is likely to change the strength of the silicate weathering feedback or

409 facilitate more efficient $\mathrm{P}$ solubilization rather to dramatically change the overall amount

410 of silicate weathering. 
To test the hypothesis that the spread of land plants caused the latest Devonian

412 expansion of marine anoxia, we used an existing model of the coupled global C-P-U cycles

413 (Clarkson et al., 2018), slightly updated to use the same U cycle and isotope mass balance

414 as in Section 5.2 (see SI for full model description). We explored various plausible

415 combinations of plant forcing factors to see under what conditions the global model could

416 reproduce the global changes observed in the latest Devonian alongside the global

417 component of the changes in the U isotope record.

418 We find that a $\sim 33 \%$ increase in land plant cover and associated chemical

419 weathering amplification over $200 \mathrm{kyr}$ is capable of generating a transient $\sim-0.6 \%$ negative

$420 \delta^{238} \mathrm{U}_{\mathrm{sw}}$ excursion, a $\sim 2 \%$ positive $\delta^{13} \mathrm{C}$ excursion, a $\sim 3^{\circ} \mathrm{C}$ global cooling, and an

421 approximate halving of $\mathrm{CO}_{2}$ levels (Fig. 7A). The anoxic fraction of the ocean increases

422 from $0.6 \%$ to a maximum of $11 \%$, and the $\mathrm{U}$ content of the ocean declines by a factor of

$423 \sim 5 \times$ (Fig. 7A). By the start of the P1 event the area of marine anoxia has doubled, and at

424 the peak of P1 it has increased $10 \times$, consistent with our interpretation of a local anoxic

425 signal at this time. Assuming a typical $+0.27 \%$ offset, the initial value of $\delta^{238} U_{\text {carb }}$

426 reasonably matches the mean of the sparse early data (before the N1 event) and the

427 predicted minimum of $\delta^{238} \mathrm{U}_{\text {carb }}$, and its timing matches the $\mathrm{N} 2$ event well (Fig. 7B, green

428 line). Assuming a $+0.6 \%$ offset (blue line), an upper limit on local $\delta^{238} \mathrm{U}_{\text {carb }}$ matches some

429 but not all of the data for the P1 and P2 events. There are of course large uncertainties in

430 the magnitude of the chemical weathering amplification terms. However, this modeling

431 exercise suggests that reasonable changes in terrestrial realm could drive the observed 432 marine perturbation. 
The expansion of terrestrial floras during the latest Devonian triggered multiple

434 effects that influenced contemporaneous marine environmental and global climatic 435 conditions. First, expanding terrestrial floras is likely to have enhanced subaerial 436 weathering of phosphorus and increased riverine P fluxes, resulting in increased marine 437 productivity and organic carbon burial (Algeo et al., 1995; Algeo and Scheckler, 1998).

438 The enhanced P delivery may be linked to slow release of organic P during transport of 439 plants to the marine realm. The effects of an increased P flux to the oceans may have been 440 amplified by enhanced phosphorus recycling from marine sediments under anoxic 441 conditions (e.g., Ingall and Jahnke, 1994; Algeo and Ingall, 2007). Second, expanding 442 terrestrial floras increased bulk silicate weathering in the pedosphere through production 443 of root acids, and contributed to increased organic carbon burial through production of 444 refractory organic matter. Collectively, these processes resulted in sharp declines in 445 atmospheric $\mathrm{CO}_{2}$ and temperatures during the Late Devonian (Berner, 2006; Algeo and 446 Scheckler, 2010). However, feedbacks with the weathering-climate system tended to limit 447 the duration of such events. For example, deep weathering of soils slowly reduces the rate 448 of liberation of new P (Algeo and Scheckler, 1998), and release of oxygen through organic 449 carbon burial slowly ventilates anoxic marine systems, limiting phosphorus recycling 450 effects (Algeo and Ingall, 2007). In our model, the oceanic anoxic event (OAE) ceased 451 after a total duration of $\sim 400 \mathrm{kyr}$. This produced a recovery in $\delta^{238} \mathrm{U}_{\mathrm{sw}}$ to more positive 452 values resembling the N2 to P2 transition, thus suggesting that the P2 event was not 453 necessarily a local sedimentary signature.

454 There may have been several pulses of enhanced weathering and expansion of 455 marine anoxia during the Late Devonian. The coupled C-P-U model with biogeochemical 
456 feedbacks (Fig. 7) predicts that a single episode of terrestrial floral expansion would have 457 generated a transient expansion of marine anoxia. In contrast, the $f_{\text {anoxic }}-\Delta_{\text {offset }}$ models (Fig.

458 5) suggest that expansion of marine anoxia would have been globally more persistent. In 459 order to generate a second expansion of marine anoxia in the C-P-U model (and match the 460 N3 data), a second episode of terrestrial floral expansion can be invoked, but again the 461 consequences would have been transient. Given the short duration of our $\delta^{238} U_{\text {carb }}$ record 462 and uncertainties surrounding its interpretation in terms of global and local signals, we 463 think it premature to propose too precise of an environmental history. Nonetheless, it is 464 encouraging that the C-P-U model can simultaneously generate several of the global 465 changes observed in the latest Devonian, consistent with the hypothesis that the spread of 466 land plants caused at least one transient oceanic anoxic event at this time.

4685.4 Marine redox changes and the Hangenberg extinction

469 Current data support a prolonged duration for the Hangenberg biotic crisis, lasting 470 from the onset of deposition of the Hangenberg black shale in the latest Devonian into the 471 earliest Carboniferous (Kaiser et al., 2008, 2011). The main phase of the Hangenberg Crisis

472 occurred at the base of the Middle praesulcata Zone, a level marked by declines in 473 conodonts, ammonoids, trilobites, stromatoporoid sponges, corals, brachiopods, bivalves, 474 and various marine phytoplankton (e.g., Caplan and Bustin, 1999; Kaiser et al., 2016).

475 Climatic cooling and global sea-level changes have been cited as causes of the Hangenberg 476 crisis (e.g., Kaiser et al., 2016), although the pattern of sea-level change during this critical 477 interval is under debate (Johnson et al., 1985; Algeo et al., 2007; Qie et al., 2015; Kaiser 478 et al., 2016). Furthermore, sedimentological evidence shows that there were sea-level 
479 fluctuations before and after deposition of the Hangenberg black shales (Walliser, 1984;

480 Johnson et al., 1985), so a direct role for sea-level changes in the biotic crisis is doubtful.

481 Here, our new $\delta^{238} U$ data highlight that, apart from any changes in sea-surface temperatures

482 and sea-level elevations, the expansion of marine anoxia in latest Devonian oceans is likely

483 to have been a key factor triggering stresses among marine organisms and communities.

484 The expansion of marine anoxia in the upper Lower Siphonodella praesulcata Zone

485 coincided with the onset of the Hangenberg biocrisis. This expansion of anoxia was vast

486 enough to have plausibly bathed the outer continental shelves and upper slope areas (i.e.,

487 when compared to a situation in the modern oceans where the shelf occupies $\sim 7 \%$ of the 488 total ocean floor).

\section{Conclusions}

491 We studied $\delta^{238} \mathrm{U}$ variations in limestones from the latest Devonian to the earliest 492 Carboniferous in the Long'an section of South China, which preserves a record of the 493 global Hangenberg Crisis. This is the first $\delta^{238} \mathrm{U}$ record for the Hangenberg Crisis. The $494 \delta^{238} \mathrm{U}$ profile of the study section shows large secular variations with three negative 495 excursions separated by two positive excursions. We suggest that these positive events are 496 best explained by intensified anoxic/sulfidic conditions in pore fluids during U uptake, 497 which captured ${ }^{238} \mathrm{U}$-enriched U(IV) in the Long'an carbonates. U isotope mass balance 498 calculations suggest that global marine anoxia expanded strongly in latest Devonian oceans, 499 covering $>5 \%$ of total global seafloor area and potentially the majority of contemporaneous 500 continental shelves. The expansion of marine anoxia in the upper Lower praesulcata Zone 501 coincided with the onset of the Hangenberg Crisis, consistent with a central role for marine 
502 anoxia in triggering the extinction event. Global modeling of the coupled C, P, U cycles

503 shows that the spread of seed plants and an associated increased continental to marine $\mathrm{P}$

504 flux could have triggered expansion of marine anoxia in latest Devonian oceans and other

505 global changes, including the positive $\delta^{13} \mathrm{C}_{\text {carb }}$ excursion and global cooling at that time,

506 but the expansion of anoxia is predicted to have been transient as P solubilization rates and

507 overall weathering intensities declined through internal feedbacks.

508

509 Acknowledgments

510 F.Z. and T.W.D. acknowledge support from the Danish Council for Independent

511 Research (No. DFF 7014-00295). T.W.D. acknowledges support from the Carlsberg

512 Foundation (grant number CF16-0876). S.Z.S.'s work is supported by the Strategic Priority

513 Research Program (B) (XDB26000000, XDB18000000). T.M.L. was supported by NERC

514 (NE/P013651 and NE/N018508/1). NJP acknowledges funding from the Packard

515 Foundation. Y.C. is supported by internal grant from Montclair State University and the

516 National Science Foundation of China (Grant 41888101). F.Z. and A.D.A. acknowledge

517 funding from the NASA Astrobiology Program (award NNX13AJ71G) and the NSF

518 Frontiers in Earth System Dynamics program (award EAR-1338810).

\section{REFERENCES}

521 Algeo, T.J., Ingall, E., 2007. Sedimentary $\mathrm{C}_{\text {org:P }} \mathrm{P}$ ratios, paleocean ventilation, and

522 Phanerozoic atmospheric $\mathrm{pO}_{2}$. Palaeogeogr. Palaeoclimatol. Palaeoecol. 256 (3), 130$523 \quad 155$.

524 Algeo, T.J., Scheckler, S.E., 1998. Terrestrial-marine teleconnections in the Devonian: 
Links between the evolution of land plants, weathering processes, and marine anoxic events. Roy. Soc. London Phil. Trans. B: Biol. Sci. 353, 113-130.

527 Algeo, T.J., Scheckler, S.E., 2010. Land plant evolution and weathering rates changes in 528 the Devonian. Journal of Earth Science (China University of Geosciences) 21, Suppl. $529 \quad 1,75-78$.

530 Algeo, T.J., Berner, R.A., Maynard, J.B., Scheckler, S.E., 1995. Late Devonian oceanic 531 anoxic events and biotic crises: "rooted" in the evolution of vascular land plants. GSA $532 \quad$ Today $5(3), 63-66$.

533 Andersen, M.B., Romaniello, S., Vance, D., Little, S.H., Herdman, R., Lyons, T.W., 2014. 534 A modern framework for the interpretation of ${ }^{238} \mathrm{U} /{ }^{235} \mathrm{U}$ in studies of ancient ocean 535 redox. Earth Planet. Sci. Lett. 400, 184-194.

536 Andersen, M.B., Stirling, C.H., Weyer, S., 2017. Uranium isotope fractionation. Rev. 537 Mineral. Geochem. 82, 799-850.

538 Banner, J.L., Hanson, G.N., 1990. Calculation of simultaneous isotopic and trace element 539 variations during water-rock interaction with applications to carbonate diagenesis. $540 \quad$ Geochim. Cosmochim. Acta 54(11), 3123-3137.

541 Becker, R., Gradstein, F., Hammer, O., 2012. The Devonian period. In: Gradstein, F.M., 542 Ogg, J.G., Schmitz, M., Ogg, G. (Eds.), The Geologic Time Scale 2012. Elsevier, 543 Amsterdam, pp. 559-601.

544 Becker, R.T., Königshof, P., Brett, C.E., 2016. Devonian climate, sea level and evolutionary 545 events: an introduction. In: Becker, R.T., Königshof, P., Brett, C.E. (Eds.), Devonian 546 Climate, Sea Level and Evolutionary Events. Geological Society, London, Special 547 Publications Vol. 423. pp. 1-11. 
Berner, R.A., 1997. The rise of plants and their effect on weathering and atmospheric $\mathrm{CO}_{2}$.

$549 \quad$ Science 276 (5312), 544-546.

550 Berner, R.A., Caldeira, K., 1997. The need for mass balance and feedback in the 551 geochemical carbon cycle. Geology $25(10), 955-956$.

552 Berner, R.A., 2006. GEOCARBSULF: a combined model for Phanerozoic atmospheric $\mathrm{O}_{2}$ 553 and $\mathrm{CO}_{2}$. Geochim. Cosmochim. Acta 70 (23), 5653-5664.

554 Brand, U., Legrand-Blain, M., Streel, M., 2004. Biochemostratigraphy of the Devonian555 Carboniferous boundary global stratotype section and point, Griotte Formation, La 556 Serre, Montagne Noire, France. Palaeogeogr. Palaeoclimatol. Palaeoecol. 205 (3-4), $557 \quad 337-357$

558 Caplan, M.L., Bustin, R.M., 1999. Devonian-Carboniferous Hangenberg mass extinction 559 event, widespread organic-rich mudrock and anoxia: causes and consequences. 560 Palaeogeogr. Palaeoclimatol. Palaeoecol. 148 (4), 187-207.

561 Caves, J.K., Jost, A.B., Lau, K.V., Maher, K., 2016. Cenozoic carbon cycle imbalances and 562 a variable weathering feedback. Earth and Planetary Science Letters 450, 152-163.

563 Chen, X., Romaniello, S.J., Herrmann, A.D., Hardisty, D., Gill, B.C., Anbar, A.D., 2018. 564 Diagenetic effects on uranium isotope fractionation in carbonate sediments from the 565 Bahamas. Geochim. Cosmochim. Acta 237, 294-311.

566 Clarkson, M.O., Stirling, C.H., Jenkyns, H.C., Dickson, A.J., Porcelli, D., Moy, C.M., 567 Pogge von Strandmann, P.A.E., Cooke, I.R., Lenton, T.M., 2018. Uranium isotope 568 evidence for two episodes of deoxygenation during Oceanic Anoxic Event 2. Proc. $569 \quad$ Natl. Acad. Sci. U.S.A. 115(12), 2918-2923.

570 Cole, D.B., Zhang, S., Planavsky, N.J., 2017. A new estimate of detrital redox-sensitive 
metal concentrations and variability in fluxes to marine sediments. Geochimica et $572 \quad$ Cosmochimica Acta 215, 337-353.

573 Dahl, T.W., Boyle, R.A., Canfield, D.E., Connelly, J.N., Gill, B.C., Lenton, T.M., Bizzarro, 574 M., 2014. Uranium isotopes distinguish two geochemically distinct stages during the 575 later Cambrian SPICE event. Earth Planet. Sci. Lett. 401, 313-326.

576 Dahl, T.W., Connelly, J., Li, D., Kouchinsky, A., Gill, B., Porter, S., Maloof, A., Bizzarro, 577 M., submitted. Atmosphere-ocean oxygenation dynames during early animal radiation. 578 In review.

579 Dunk, R.M., Mills, R.A., Jenkins, W.J., 2002. A reevaluation of the oceanic uranium budget 580 for the Holocene. Chem. Geol. 190(1-4), 45-67.

581 Henderson, G., Slowey, N., Haddad, G., 1999. Fluid flow through carbonate platforms: 582 constraints from ${ }^{234} \mathrm{U} /{ }^{238} \mathrm{U}$ and $\mathrm{Cl}^{-}$in Bahamas pore-waters. Earth Planet. Sci. Lett. 169, $583 \quad 99-111$.

584 Ingall, E., Jahnke, R., 1994. Evidence for enhanced phosphorus regeneration from marine 585 sediments overlain by oxygen depleted waters. Geochim. Cosmochim. Acta 58 (11), $586 \quad 2571-2575$.

587 Jacobsen, S.B., Kaufman, A.J., 1999. The Sr, C and O isotopic evolution of Neoproterozoic $588 \quad$ seawater. Chem. Geol. 161(1-3), 37-57.

589 Joachimski, M.M., Buggisch, W., 2002. Conodont apatite $\delta^{18} \mathrm{O}$ signatures indicate climatic 590 cooling as a trigger of the Late Devonian mass extinction. Geology 30 (8), 711-714. 591 Joachimski, M. M., Breisig, S., Buggisch, W., Talent, J. A., Mawson, R., Gereke, M., 592 Morrow, J. R., Day, J., and Weddige, K., 2009. Devonian climate and reef evolution: 593 Insights from oxygen isotopes in apatite. Earth Planet. Sci. Lett. 284, 599-609. 
Johnson, J., Klapper, G., Sandberg, C.A., 1985. Devonian eustatic fluctuations in Euramerica. Geol. Soc. Am. Bull. 96 (5), 567-587.

Kaiser, S.I., Steuber, T., Becker, R.T., Joachimski, M.M., 2006. Geochemical evidence for major environmental change at the Devonian-Carboniferous boundary in the Carnic Alps and the Rhenish Massif. Palaeogeogr. Palaeoclimatol. Palaeoecol. 240 (1-2), $146-160$.

Kaiser, S.I., Steuber, T., Becker, R.T., 2008. Environmental change during the Late Famennian and Early Tournaisian (Late Devonian-Early Carboniferous): implications

604 Kaiser, S.I., Becker, R.T., Steuber, T., Aboussalam, S.Z., 2011. Climate-controlled mass 605 extinctions, facies, and sea-level changes around the Devonian-Carboniferous 606 boundary in the eastern Anti-Atlas (SE Morocco). Palaeogeogr. Palaeoclimatol. Palaeoecol. 310 (3-4), 340-364.

608 Kaiser, S.I., Aretz, M., Becker, R.T., 2016. The global Hangenberg Crisis (Devonian609 Carboniferous transition): review of a first-order mass extinction: Geological Society, $610 \quad$ London, Special Publications 423, 387-437.

611 Koschinsky, A., Hein, J.R., 2003. Uptake of elements from seawater by ferromanganese 612 crusts: solid-phase associations and seawater speciation. Mar. Geol. 198 (3-4), 331$613 \quad 351$.

614 Lau, K.V., Maher, K., Altiner, D., Kelley, B.M., Kump, L.R., Lehrmann, D.J., Silva615 Tamayo, J.C., Weaver, K.L., Yu, M., Payne, J.L., 2016. Marine anoxia and delayed 616 Earth system recovery after the end-Permian extinction. Proc. Natl. Acad. Sci. U.S.A. 
618 Lau, K.V., Macdonald, F.A., Maher, K., Payne, J.L., 2017. Uranium isotope evidence for 619 temporary ocean oxygenation in the aftermath of the Sturtian Snowball Earth. Earth $620 \quad$ Planet. Sci. Lett. 458, 282-292.

621 Le Hir, G., Donnadieu, Y., Goddéris, Y., Meyer-Berthaudd, B., Ramstein, G., Blakey, B.C., 622 2011. The climate change caused by the land plant invasion in the Devonian. Earth 623 Planet. Sci. Lett. 310 (3-4), 203-212.

624 Lenton, T.M., 2001. The role of land plants, phosphorus weathering and fire in the rise and 625 regulation of atmospheric oxygen. Global Change Biol. 7,613-629.

626 Liu, J., Qie, W., Algeo, T.J., Yao, L., Huang, J., Luo, G., 2016. Changes in marine nitrogen 627 fixation and denitrification rates during the end-Devonian mass extinction. 628 Palaeogeogr. Palaeoclimatol. Palaeoecol. 448, 195-206.

629 Liu, J., Luo, G., Lu, Z., Lu, W., Qie, W., Zhang, F., Wang, X., Xie, S., 2018. Shoaling of 630 oxygen minimum zone induced the end Devonian mass extinction. Geochem. 631 Geophys., in press.

632 Marynowski, L., Filipiak, P., 2007. Water column euxinia and wildfire evidence during 633 deposition of the Upper Famennian Hangenberg event horizon from the Holy Cross 634 Mountains (central Poland). Geol. Mag. 144 (3), 569-595.

635 Marynowski, L., Zatoń, M., Rakociński, M., Filipiak, P., Kurkiewicz, S., Pearce, T.J., 2012. 636 Deciphering the upper Famennian Hangenberg Black Shale depositional environments 637 based on multi-proxy record. Palaeogeogr. Palaeoclimatol. Palaeoecol. 346, 66-86.

638 McArthur, J.M., Howarth, R.J., Shields, G.A., 2012. Strontium isotope stratigraphy. In: 639 Gradstein, F.M., Ogg, J.G., Schmitz, M.D., Ogg, G.M., eds., The Geologic Time Scale 
641 Qie, W., Liu, J., Chen, J., Wang, X., Mii, H.-s., Zhang, X., Huang, X., Yao, L., Algeo, T.J., 642 Luo, G., 2015. Local overprints on the global carbonate $\delta^{13} \mathrm{C}$ signal in Devonian643 Carboniferous boundary successions of South China. Palaeogeogr. Palaeoclimatol. $644 \quad$ Palaeoecol. 418, 290-303.

645 Romaniello, S.J., Herrmann, A.D., Anbar, A.D., 2013. Uranium concentrations and $646{ }^{238} \mathrm{U} /{ }^{235} \mathrm{U}$ isotope ratios in modern carbonates from the Bahamas: Assessing a novel 647 paleoredox proxy. Chem. Geol. 362, 305-316.

648 Rudnick, R., Gao, S., 2014. Composition of the continental crust. In Treatise on 649 Geochemistry (eds. H. D. Holland and K. K. Turekian), second ed. Elsevier, Oxford, $650 \quad$ pp. $1-51$.

651 Sallan, L.C., Coates, M.I., 2010. End-Devonian extinction and a bottleneck in the early 652 evolution of modern jawed vertebrates. Proc. Natl. Acad. Sci. U.S.A. 107 (22), $10131-$ $653 \quad 10135$

654 Schieber, J., 2009. Discovery of agglutinated benthic foraminifera in Devonian black 655 shales and their relevance for the redox state of ancient seas. Palaeogeogr. 656 Palaeoclimatol. Palaeoecol. 271, 292-300.

657 Scotese, C.R., McKerrow, W.S., 1990. Revised World maps and introduction. In: 658 McKerrow, W.S., Scotese, C.R. (Eds.), Palaeozoic Palaeogeography and Biogeography. 659 Geological Society of London Memoir 12, pp. 1-21.

660 Tissot, F.L.H., Chen, C., Go, B.M., Naziemiec, M., Healy, G., Bekker, A., Swart, P.K., 661 Dauphas, N., 2018. Controls of eustasy and diagenesis on the ${ }^{238} U /{ }^{235} \mathrm{U}$ of carbonates 662 and evolution of the seawater ${ }^{234} \mathrm{U} /{ }^{238} \mathrm{U}$ during the last 1.4 Myr. Geochim. Cosmochim. 
Acta 242, 233-265.

664 Tribovillard, N., Averbuch, O., Devleeschouwer, X., Racki, G., Riboulleau, A., 2004. Deep

665 water anoxia over the Frasnian-Famennian boundary (La Serre, France): a tectonically

666 induced oceanic anoxic event? Terra Nova 16, 288-295.

667 Tribovillard, N., Algeo, T.J., Lyons, T., Riboulleau, A., 2006. Trace metals as paleoredox 668 and paleoproductivity proxies: an update. Chem. Geol. 232, 12-32.

669 Veizer, J., Ala, D., Azmy, K., Bruckschen, P., Buhl, D., Bruhn, F., Carden, G.A.F., Diener,

670 A., Ebneth, S., Godderis, Y., Jasper, T., Korte, C., Pawellek, F., Podlaha, O., Strauss, 671 H., 1999. ${ }^{87} \mathrm{Sr} /{ }^{86} \mathrm{Sr}, \delta^{13} \mathrm{C}$ and $\delta^{18} \mathrm{O}$ evolution of Phanerozoic seawater. Chem. Geol. 161, $672 \quad 59-88$

673 Walliser, O.H., 1984. Pleading for a natural D/C boundary. Cour. Forschungsinstitut $674 \quad$ Senckenberg 67, 241-246.

675 White, D.A., Elrick, M., Romaniello, S., Zhang, F., 2018. Global seawater redox trends 676 during the Late Devonian mass extinction detected using $U$ isotopes of marine 677 limestones. Earth Planet. Sci. Lett. 503, 68-77.

678 Zhang, F., Algeo, T.J., Romaniello, S., Cui, Y., Zhao, L., Chen, Z.Q., Anbar, A.D., 2018a.

679 Congruent Permian-Triassic $\delta^{238} \mathrm{U}$ records at Panthalassic and Tethyan sites: 680 Confirmation of global oceanic anoxia and validation of the U-isotope paleoredox 681 proxy. Geology 46(4), 327-330.

682 Zhang, F., Romaniello, S.J., Algeo, T.J., Lau, K.V., Clapham, M.E., Richoz, S., Herrmann, 683 A.D., Smith, H., Horacek, M., Anbar, A.D., 2018b. Multiple episodes of extensive 684 oceanic anoxia linked to global warming and continental weathering following the $685 \quad$ latest Permian mass extinction. Science Advances 4(4), e1602921. 
686 Zhang F., Xiao, S., Kendall, B., Romaniello, S.J., Cui, H., Meyer, M., Gilleaudeau, G.J., 687 Kaufman, A.J., Anbar, A.D., 2018c. Extensive marine anoxia during the terminal $688 \quad$ Ediacaran Period. Science Advances 4:eaan8983.

689 Zhang, F., Algeo, T.J., Cui, Y., Shen, J., Song, H.Y., Sano, H., Rowe, H.D., Anbar, A.D., 690 2019a. Global-ocean redox variation across the Smithian-Spathian boundary linked to 691 concurrent climatic and biotic changes. Earth-Science Reviews 195, 147-168.

692 Zhang, F., Xiao, S., Romaniello, S.J., Hardisty, D., Li, C., Melezhik, V., Pokrovsky, B., 693 Cheng, M., Shi, W., Lenton, T.M., Anbar, A.D., 2019b. Global marine redox changes 694 drove the rise and fall of the Ediacara biota. Geobiology 17 (6), 594-610.

695

696 
699 Figure 1 Late Devonian paleogeography. (A) Global paleogeography (modified from

700 Scotese and McKerrow, 1990). The red rectangle represents the area of map B. (B) South

701 China paleogeography (modified from Qie et al., 2015). Study locale is shown by star: LA:

702 Long'an.

703

704 Figure $2 \delta^{238} \mathbf{U}, \delta^{13} C_{\text {carb }}$, and $\delta^{15} \mathbf{N}_{\text {bulk }}$ profiles of Long'an section in South China. L 705 Carbon., Lower Carboniferous; Fm., Formation; Lithol., Lithology; HE, Hangenberg 706 Extinction. P1 and P2 denote positive $\delta^{238} \mathrm{U}$ excursions, and N1, N2, and N3 denote 707 negative $\delta^{238} \mathrm{U}$ excursions.

709 Figure 3 Trace element profiles and elemental ratios of Long'an section. The 710 orange/blue shaded area denotes horizons affected by sulfidic/anoxic pore-water 711 conditions.

713 Figure 4 Mass balance calculations of fraction of uranium removal to anoxic sinks 714 based on diagenetic offsets $\left(\Delta_{\text {offset }}\right)$ of $0 \%$, $0.27 \%$, and $0.3 \%$. Two independent 715 calculations using fractionation factors between seawater and anoxic sinks of $0.6 \%$ 716 and $\mathbf{0 . 8 5 \%}$, respectively, are shown for comparison.

718 Figure $5 \mathrm{U}$ isotope model estimates of local versus global expansion of marine anoxia.

719 In model scenario 1 (MS1), anoxic marine areas initially started from an oxygenated ocean 
720 similar to the modern-day, which started to expand at peak of P1. The local anoxia in the

721 model is assumed to be proportional to the $\Delta_{\text {offset }}$ that can be generated between average

722 carbonates and anoxic carbonates. The $\Delta_{\text {offset }}$ varies between $0.27 \%$ and $0.6 \%$. The model

723 scenario 2 (MS2) started from a situation similar to that in MS1 but expanded prior to peak

724 of P1 and further expanded between P1 and N2.

725

726 Figure 6 Distribution of $\Delta_{\text {offset }}\left(\delta^{238} \mathbf{U}_{\text {carbonate }} \delta^{238} \mathbf{U}_{\text {seawater }}\right)$ in model scenario 1, model 727 scenario 2, and CPU model (Fig. 7) for Long'an compared to modern carbonates. In

728 model scenario 1 , the average $\Delta_{\text {offset }}$ is similar to that of modern carbonates but the Long'an

729 section displays more scatter. In model scenario 2 , both the average $\Delta_{\text {offset }}$ value and its

730 variability is greater for the Long'an section than observed in modern carbonates.

732 Figure 7 Global $\mathbf{C}, \mathbf{P}, \mathbf{U}$ model scenario of increased land plant cover and enhanced 733 continental weathering as a cause of coupled global changes. (A) Model scenario of a $73433 \%$ increase in plant cover (V) and associated bulk weathering amplification (W) over $735200 \mathrm{kyr}$ starting at 359.28 Ma, and resulting response of normalized P content of ocean $736\left(\mathrm{P} / \mathrm{P}_{0}\right)$, anoxic fraction of ocean (fanoxic), $\mathrm{CO}_{2}(\mathrm{PAL}), \delta^{13} \mathrm{C}(\%)$, normalized $\mathrm{U}$ content of 737 ocean $\left(\mathrm{U} / \mathrm{U}_{0}\right)$, and $\delta^{238} \mathrm{U}_{\mathrm{sw}}(\%)$. (B) Comparison of data (symbols), running mean of data 738 (red line), and modelled $\delta^{238} U_{\text {sw }}$ (blue line), assuming a fixed offset $\left(0.27 \%\right.$ of $\delta^{238} U_{\text {carb }}$

739 from seawater $\delta^{238} \mathrm{U}$ (green line), and maximum $\delta^{238} \mathrm{U}_{\text {carb }}$ assuming a maximum offset of $740 \quad 0.6 \%$ from seawater (purple line). (Note the shift in the time axis between panels $\mathrm{A}$ and 741 B.) 
743 Figure 1

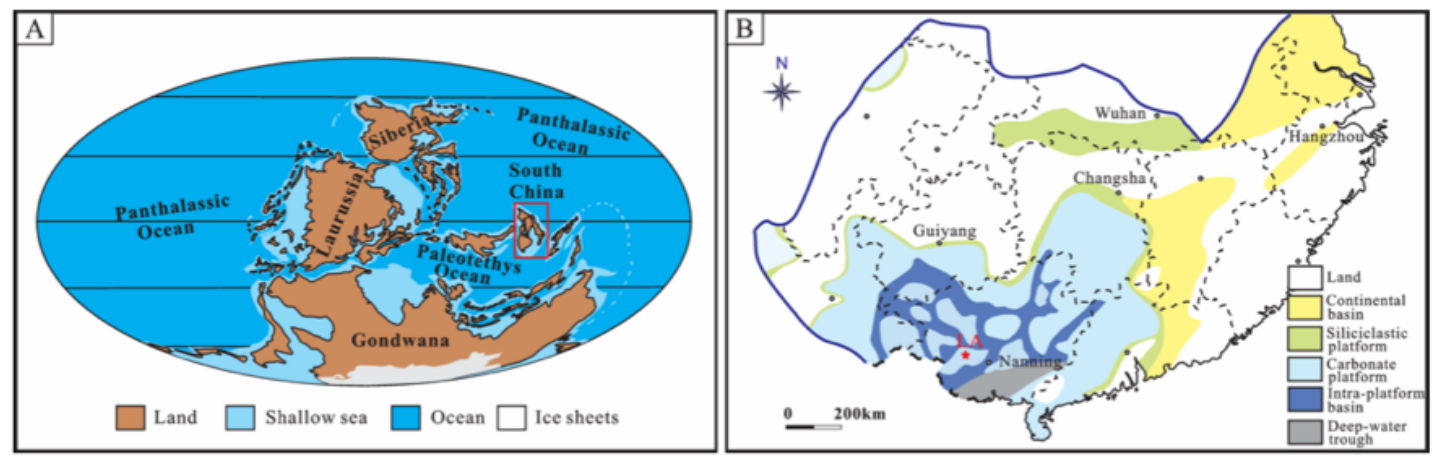

745

746 
Figure 2

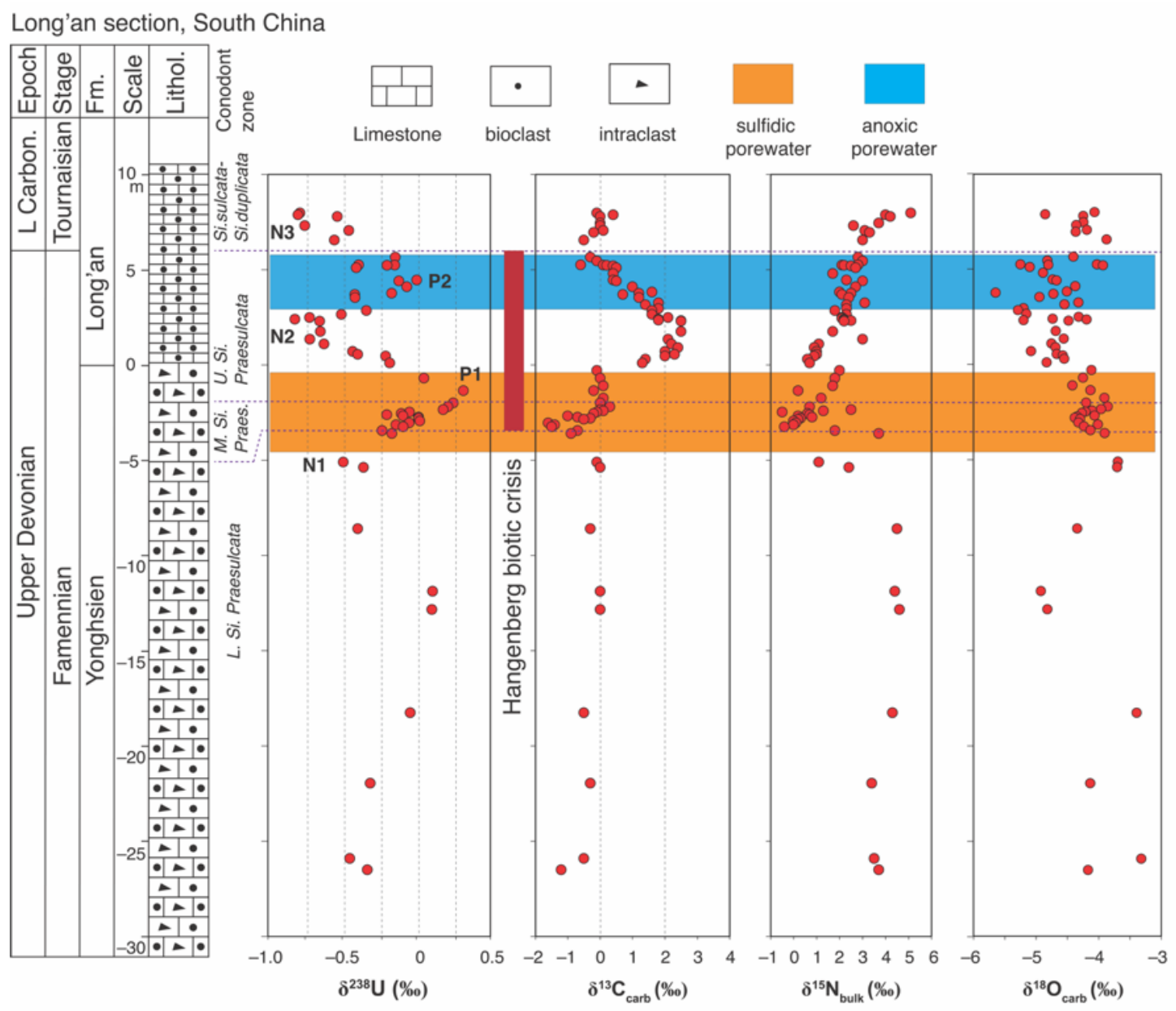

748 
752 Figure 3

753

754

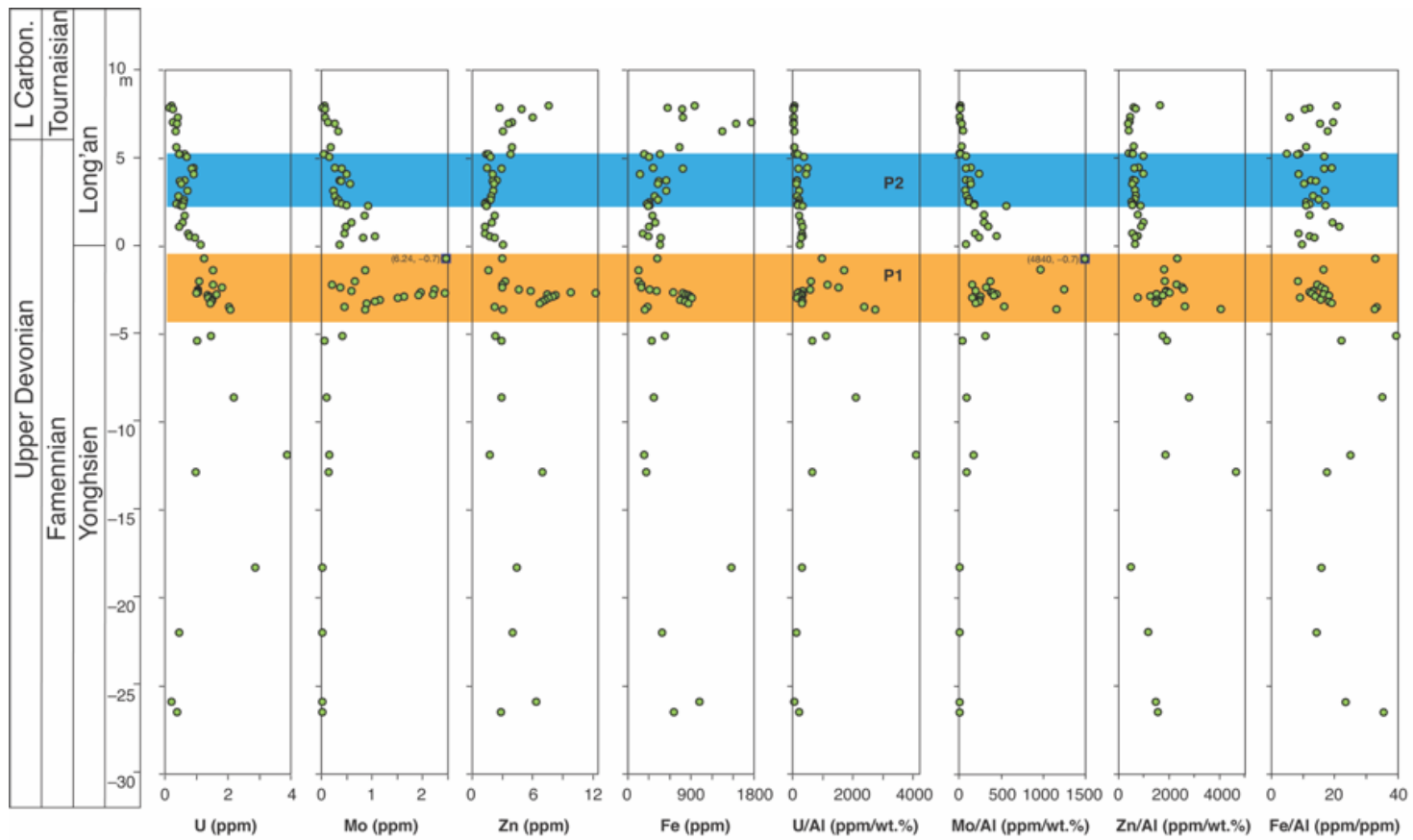


$755 \quad$ Figure 4

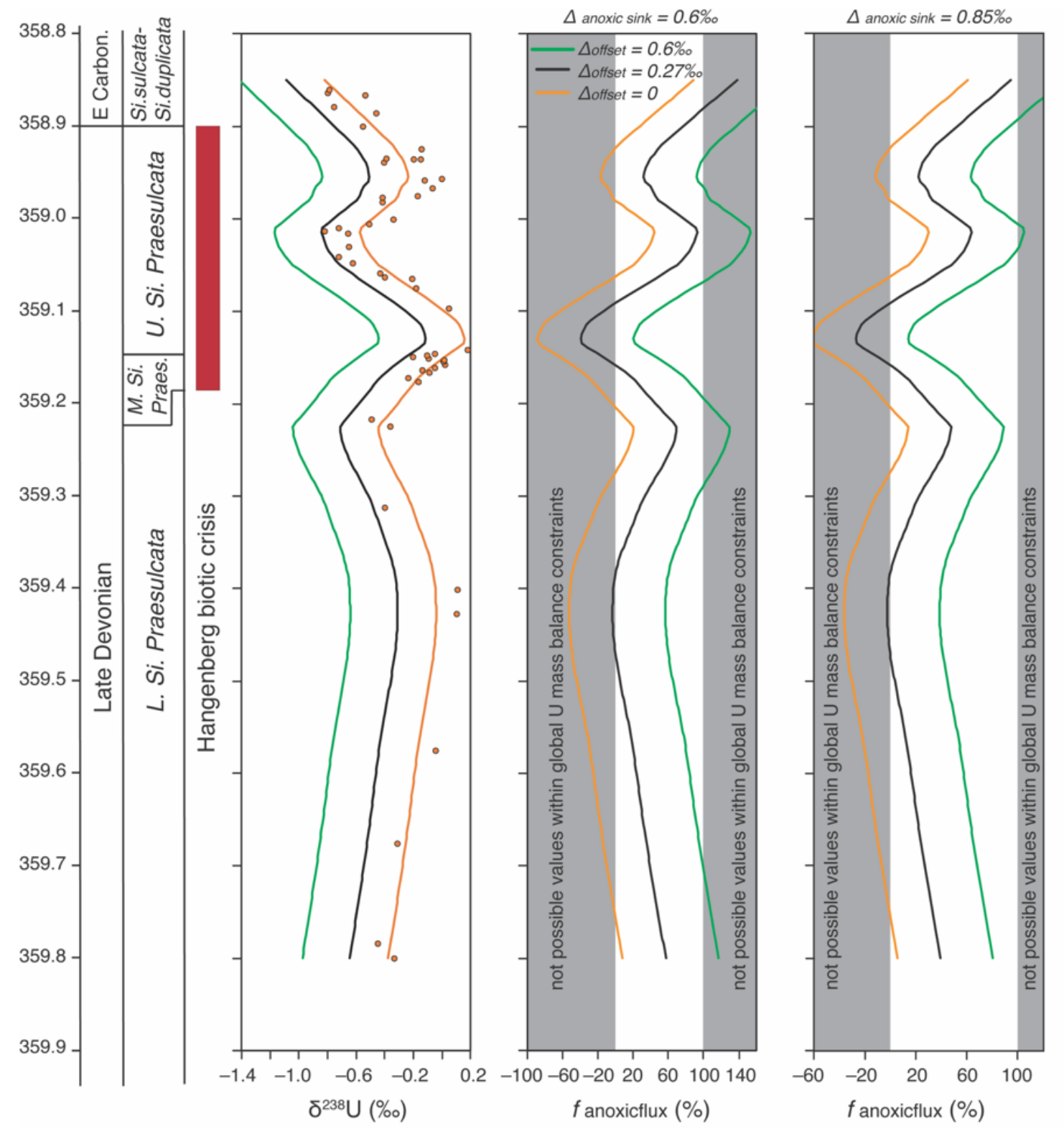


757 Figure 5
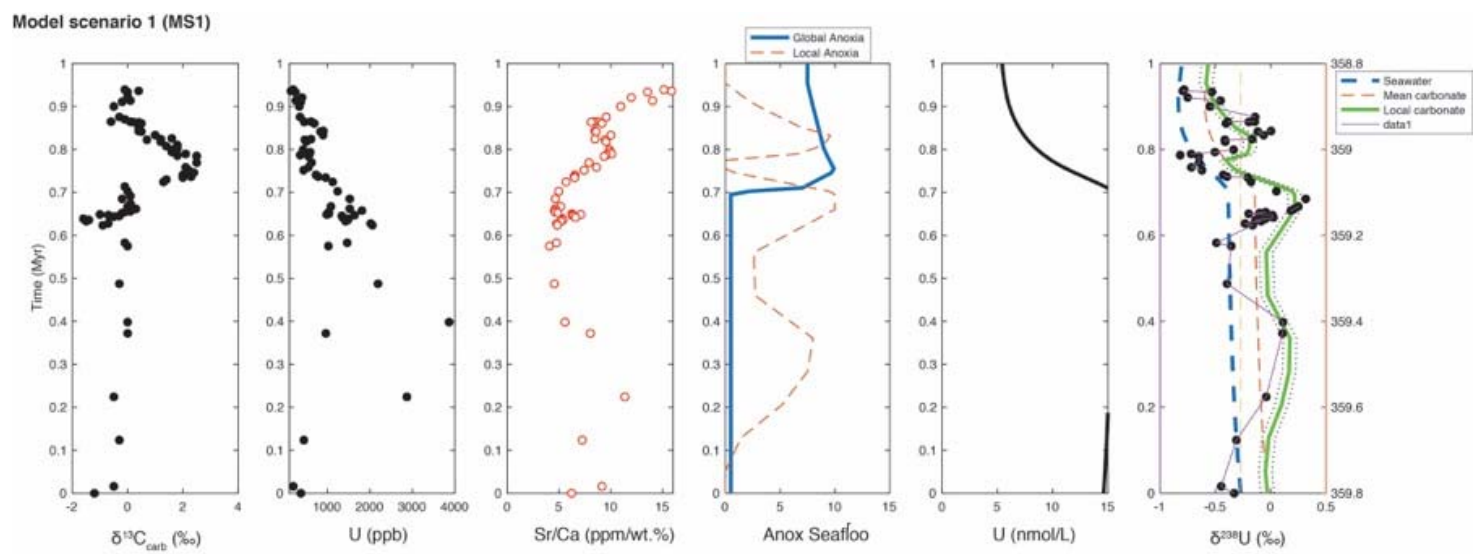

Model scenario 2 (MS2)
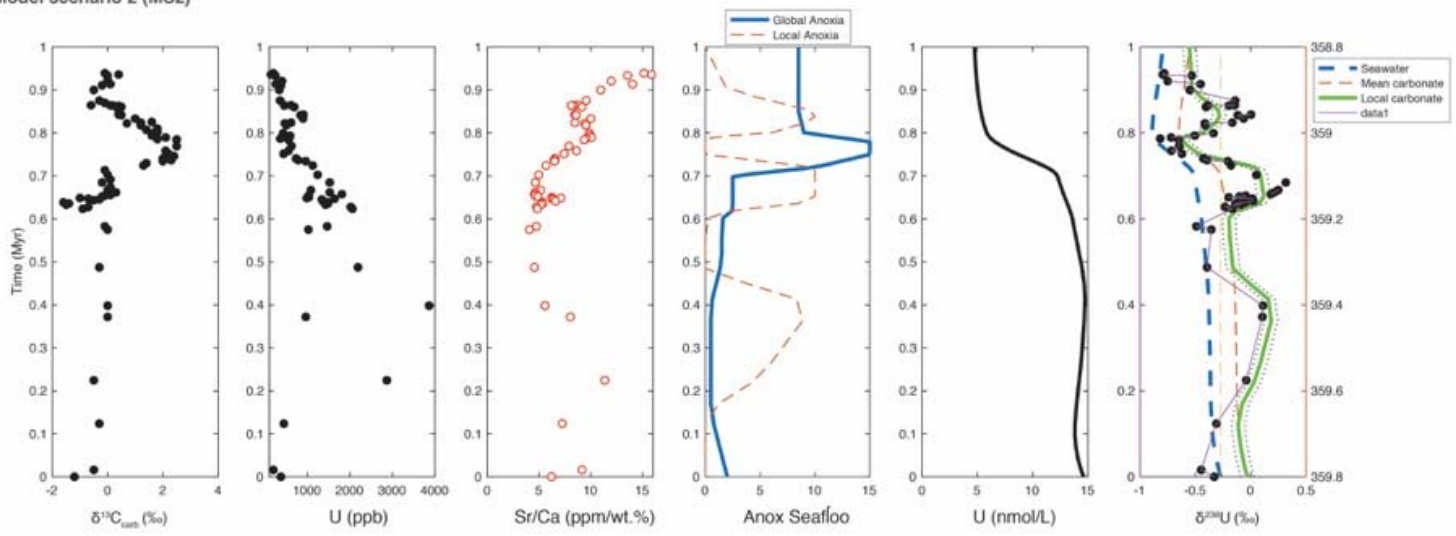

759

760

761

762 
Figure 6
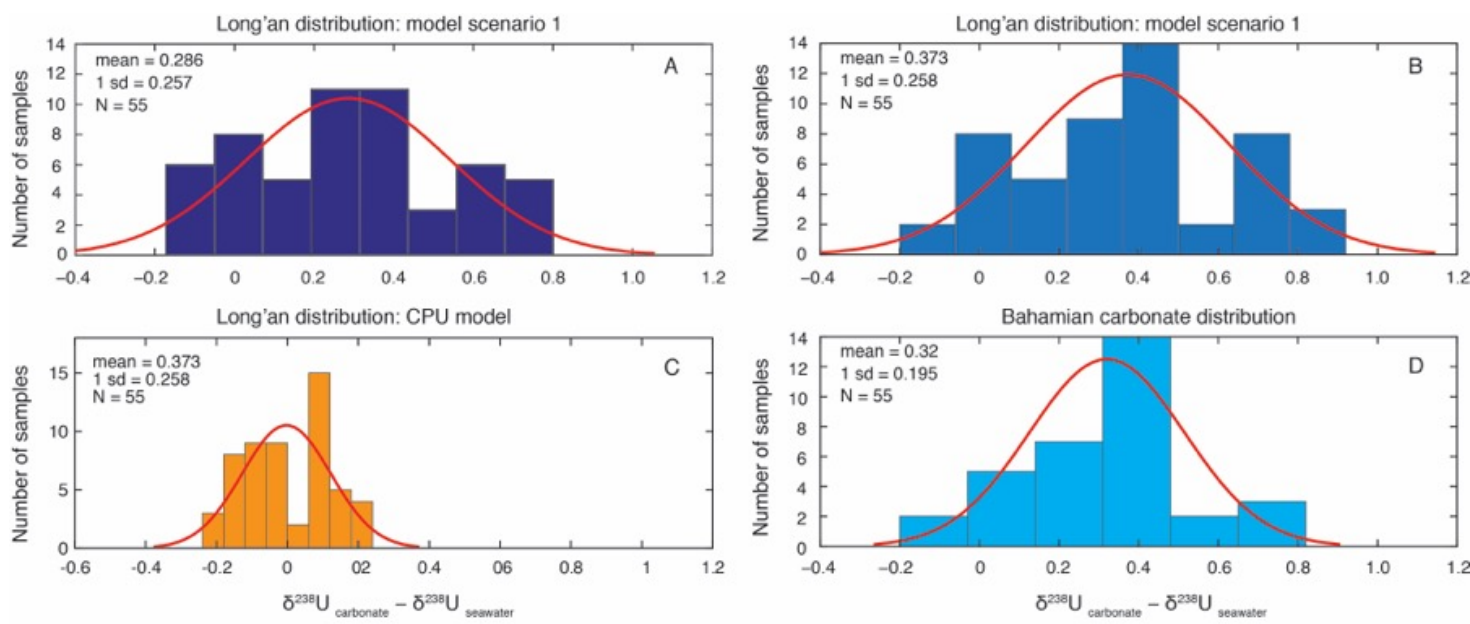

765

766 
Figure 7

768

769
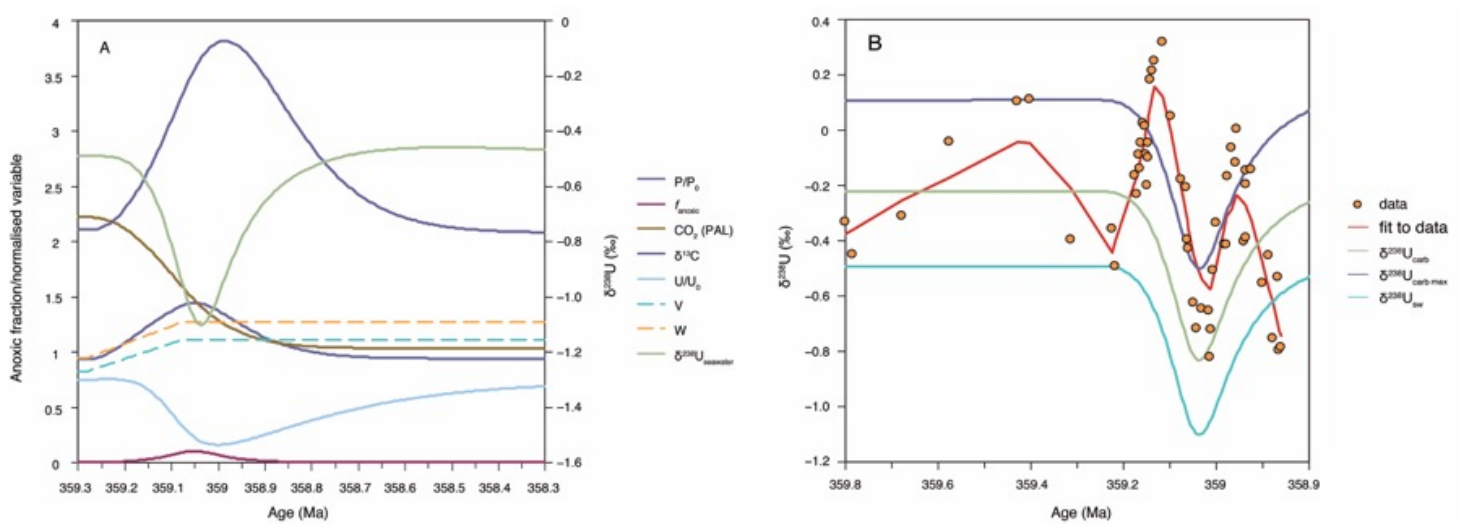

770

771 
773 Table 1 Uranium box model parameterization.

\begin{tabular}{|c|c|c|c|}
\hline Model parameters & & Modern & Reference \\
\hline Ocean volume & $\mathrm{V}_{\text {ocean }}$ & $1.30 \mathrm{E}+21$ & $\bar{L}$ \\
\hline Oceanic U inventory & $\mathrm{N}_{\mathrm{sw}}$ & $1.90 \mathrm{E}+13$ & mol \\
\hline Anoxic seafloor area & $\mathrm{A}_{\text {anoxic }}$ & $0.5 \%$ & $\begin{array}{l}\text { ( } \% \text { of total } \\
\text { seafloor) }\end{array}$ \\
\hline
\end{tabular}

Fluxes aeolian)

Sediment burial flux in anoxic settings

Sediment burial flux in other settings $\quad \mathrm{J}_{\text {other }}$

$\begin{array}{lll}5.30 \mathrm{E}+7 & \mathrm{~mol} / \mathrm{yr} & \text { Dunk et al., 2002 } \\ 1.17 \mathrm{E}+7 & \mathrm{~mol} / \mathrm{yr} & \text { Dunk et al., 2002 } \\ 4.64 \mathrm{E}+7 & \mathrm{~mol} / \mathrm{yr} & \text { Dunk et al., 2002 }\end{array}$

\section{Uranium isotope cycle}

Uranium isotope composition of oceanic input

Uranium isotope difference between buried anoxic sediments and seawater Uranium isotope difference between buried other sediments and seawater Uranium isotope difference between carbonates and seawater

Maximal U isotope offset in carbonates $\delta^{238} U_{\text {river }} \quad-0.27 \quad \%$ Andersen et al., 2017 $\Delta^{238} \mathrm{U}_{\text {anoxic }} \quad+0.60 \quad \%$ Andersen et al., 2017

$\Delta^{238} \mathrm{U}_{\text {other }} \quad+0.05 \quad \%$

Dahl et al., 2014

Local conditions at Long'an

$\Delta^{238} \mathrm{U}_{\text {carb }} \quad+0.24$

$\%$

Chen et al., 2018

$\Delta_{\text {offset, maz }}$

$+0.60$

$\%$

Romaniello et al., 2013

$\Delta_{\text {offset }}$

change with time 